\title{
Anticancer studies on methanolic extract of aerial parts of Uraria Picta (Jacq.) DC
}

\author{
Abu Sufiyan Chhipa ${ }^{1,2^{*}}$, Ruma Baksi ${ }^{1,3}$ and Manish Nivsarkar ${ }^{1}$
}

\begin{abstract}
Background: Uraria picta (Jacq.) DC is a traditional Indian herb used in the Ayurvedic system of medicine. It is an ingredient of the popular Ayurvedic formulation "Dasamoola." It is also traditionally used as an anti-inflammatory herb in Ayurveda. The plant also has excellent antioxidant potential. Different parts of Uraria picta are useful and have diverse medicinal properties. The present investigation was done to evaluate the anticancer activity of methanolic extract of aerial parts of Uraria picta (Jacq.).

Results: Preliminary phytochemical screening of MEUP confirmed the presence of flavonoids, phenolics, glycosides, and tannins. Total phenolic and flavonoid contents in MEUP were found to be 14.6 gram equivalent of gallic acid and 0.735 gram equivalent of catechin, respectively. IC50 values of cisplatin and MEUP were found to be $8.75 \mu \mathrm{g} / \mathrm{ml}$ and $436.92 \mu \mathrm{g} / \mathrm{ml}$, respectively. Induction of apoptosis was evident from DAPI staining showing a dose-dependent increase in apoptosis. Also, a reduction in intracellular ROS was evident from the DCFH-da assay, where a dosedependent decrease in intracellular ROS (fluorescence) was observed. Significant reduction $(P<0.05)$ in tumor volume was observed in mice receiving cisplatin and MEUP at both dose levels.
\end{abstract}

Conclusion: The methanolic extract of aerial parts of Uraria picta (Jaca.) DC is effective in inhibiting tumor growth and has significant anticancer property.

Keywords: Anticancer, MEUP, Uraria picta (Jacq.) DC, Antitumor, ROS, Apoptosis

\section{Background}

Cancer is a multifactorial disease characterized by an abnormal and uncontrolled cell growth that is capable of invading the surrounding tissues and distant organs [1]. Cancer accounts for 9.6 million deaths worldwide in the year 2018. Moreover, around 18.1 million new cases of cancer occurred in the same year, making it a leading cause of deaths globally [2]. In the USA, cancer stands as the second most common cause of deaths after cardiovascular diseases, responsible for around $25 \%$ of total deaths per year $[3,4]$. Lung cancer stands as the most

\footnotetext{
* Correspondence: asufiyanchhipa@gmail.com

'Department of Pharmacology and Toxicology, B. V. Patel Pharmaceutical Education and Research Development (PERD) Centre, Thaltej, Ahmedabad, Gujarat 380054, India

2Institute of Pharmacy, Nirma University, Sarkhej- Gandhinagar Highway, Ahmedabad 382481, Gujarat, India

Full list of author information is available at the end of the article
}

common cancer in both males and females globally with tobacco smoking as the major risk factor $[2,5]$.

Cancer chemotherapy is the most widely employed approach for cancer treatment. However, a major concern associated with chemotherapy is the occurrence of severe side effects during the course of treatment [6]. Natural products and secondary metabolites isolated from plant sources are considered to be less toxic to normal cells [7]. A majority of anticancer agents that are employed in the present scenario for the treatment of cancer are obtained from plant sources. Secondary metabolites including alkaloids, flavonoids, sesquiterpines, polyphenols, etc. are widely utilized as anticancer agents [7]. Data from FDA reports suggest that $40 \%$ of approved anticancer molecules are natural compounds and a majority of them are presently utilized in anticancer therapy $[7,8]$. 
Uraria picta (Jacq.) DC is a perennial herb found in Australia and Africa and in almost all parts of Asia, including India. It is an ingredient of a popular ayurvedic formulation "Dashmula/Dasamoola "[9]. The plant is found to be rich in secondary metabolites including alkaloids, flavonoids, steroids, terpenoids, phenols, saponins tannins, and cardiac glycosides [10]. Uraria picta (Jacq.) DC is claimed to have anti-inflammatory, antipyretic, and aphrodisiac properties in the traditional system of medicine in India [11]. Acaricidal and antimicrobial properties of the plant are also reported [12, 13]. Results from preclinical studies also suggested excellent anti-inflammatory activity of the plant [14]. Inflammation plays crucial roles in cancer. It mediates the expansion of the tumor microenvironment to accelerate the tumor proliferation and supports the survival and migration of cancer cells $[15,16]$. Multiple studies have suggested that drugs targeting the inflammatory pathways result in attenuated growth of cancer cells [17]. Moreover, the plant is also found to have a significant antioxidant property. Therefore, Based on its traditional antiinflammatory and reported antioxidant claims [18], the present study was carried out to evaluate the anticancer effects of methanolic extract of aerial parts of Uraria picta (Jacq.) DC.

\section{Methods}

\section{Reagents}

Marketed preparations of cyclophosphamide (injections, Sigma-Aldrich), cyclosporine (ampoules, Biocon Ltd., India), ketoconazole (tablets, Albatross Pharmaceuticals, India), ampoxin (injections, Unichem Laboratories, India), and cisplatin (MP Biomedicals ) were used in the study. Fetal bovine serum (FBS), trypsin EDTA solution, 3-(4, 5-dimethylthiazol-2-yl)-2,5-diphenyltetrazolium bromide) (MTT), antibiotic and antimycotic preparations, trypan blue $0.4 \%$, and Roswell Park Memorial Institute (RPMI) 1640 medium were purchased from HiMedia Laboratories Pvt. Ltd., India. 4, 6 Diamino-2 phenylindole (DAPI), 2, 7-dichlorofluoresceindiacetate (DCFH-da) dyes were purchased from sigma.

\section{Cell line and animals}

The A549 human lung cancer cell line was obtained from the National Centre for Cell Science (NCCS), Pune, Maharashtra, and was maintained at $37^{\circ} \mathrm{C}$ in RPMI1640 medium supplemented with $10 \%$ FBS under $5 \%$ $\mathrm{CO}_{2}$ and humidified condition in a $\mathrm{CO}_{2}$ incubator [19, 20]. Six-week-old C57bl6 mice were obtained from Mahaveera Enterprises, Hyderabad, India (Registration no: $1656 / \mathrm{PO} / \mathrm{bt} / \mathrm{S} / 12 / \mathrm{CPCSEA})$. Animals were of both sexes. The average weights of animals were between 25 and $30 \mathrm{~g}$. The protocol for the study was presented in the Institutional Animal Ethics Committee (IAEC) meeting, and was approved on 20/10/2018. An approval certificate was issued by the committee with Protocol number: PERD/IAEC/2018/014.

\section{Collection of plant material}

Uraria picta (Jacq.) DC was collected in the month of October 2018 from Gandhi Bazar, Ahmedabad, Gujarat. The plant was authenticated by a taxonomist. A voucher specimen was submitted to the department (Voucher specimen number: BVPPERD/PP/1118/809). Plant material was shade dried, powdered, and stored in an airtight container.

\section{Preparation of methanolic extract of Uraria picta (Jacq.) $D C$}

Powdered aerial plant parts of Uraria picta were weighed $(300 \mathrm{~g})$ and suspended in a conical flask containing methanol $(2 \mathrm{~L})$. The suspension was kept undisturbed for 3 days with occasional shaking. The procedure was repeated twice with the remaining marc to achieve the complete extraction of phytoconstituents. Total filtrate obtained was combined and kept in a rotavapor apparatus at $50{ }^{\circ} \mathrm{C}$ to evaporate methanol. Methanolic extract of Uraria picta (MEUP) after solvent evaporation was combined, weighed and its percent yield was calculated [21].

\section{Preliminary phytochemical screening of extract}

The preliminary phytochemical analysis of the MEUP was carried out to confirm the presence of different classes of the phytoconstituents in the extract including tannins, flavonoids, alkaloids, saponins, glycosides, and polyphenols [22].

\section{Estimation of total phenolic content}

Estimation of total phenolics in MEUP was carried out. Extraction of powdered plant material $(500 \mathrm{mg})$ was done in $50 \%$ aqueous methanol. Filtrate was collected after extraction and the volume of the filtrate was made up to $50 \mathrm{ml}$ with methanol. For estimation, $10 \mathrm{ml}$ of double-distilled water and $1.5 \mathrm{ml}$ of the Folin-Coicalteu reagent was added to $0.1 \mathrm{ml}$ of the extract; and the solution was incubated for $5 \mathrm{~min}$. To this, $4 \mathrm{ml}$ of $20 \%$ sodium carbonate was added and the volume of the solution was made up to $25 \mathrm{ml}$ with double-distilled water, mixed thoroughly, and incubated at room temperature for $30 \mathrm{~min}$. The absorption of the mixture was recorded at $765 \mathrm{~nm}$. Gallic acid $(100 \mu \mathrm{g} / \mathrm{ml})$ was used as standard. Total phenolic content in MEUP was expressed as gallic acid equivalent (GAE) [23].

\section{Estimation of total flavonoid content}

Estimation of total flavonoid in MEUP was done by adding $125 \mu \mathrm{L}$ of MEUP solution in methanol to $75 \mu \mathrm{L}$ of 
$5 \% \mathrm{NaNO}_{2}$ solution. The resulting mixture was allowed to stand for $6 \mathrm{~min}$, followed by the addition of $150 \mu \mathrm{L}$ of aluminum trichloride (10\%) and further incubation for 5 min. The final volume of solution was adjusted to $2.5 \mathrm{ml}$ with distilled water after the addition of $750 \mu \mathrm{L}$ of $\mathrm{NaOH}$ $(1 \mathrm{M})$, incubated for $15 \mathrm{~min}$, and allowed to acquire a pink appearance. Absorbance was measured at $510 \mathrm{~nm}$. Catechin was used as standard. The total flavonoid content in MEUP was expressed as catechin equivalent (CE) [24].

\section{MTT assay}

The MTT assay is based on the principle that the mitochondrial dehydrogenase enzyme of live cells reduces the yellow MTT (3-[4,5-dimethylthiazol-2-yl]-2,5 diphenyl tetrazolium bromide) dye into purple formazan crystals [25]. MTT assay was done to assess the cytotoxicity of MEUP against A549 cancer cells. A549 human lung cancer cells were maintained at $37^{\circ} \mathrm{C}$ in RPMI 1640 medium supplemented with $10 \% \mathrm{FBS}$ under $5 \% \mathrm{CO}_{2}$ and $95 \%$ air in a $\mathrm{CO}_{2}$ incubator. Cells were seeded in a 96 well plate $(10,000$ cells/well) and incubated for $24 \mathrm{~h}$. After the incubation period, media was discarded and cells were treated with different concentrations of MEUP $(37.5 \mu \mathrm{g} / \mathrm{ml}, 75 \mu \mathrm{g} / \mathrm{ml}, 150 \mu \mathrm{g} / \mathrm{ml}, 300 \mu \mathrm{g} / \mathrm{ml}, 450 \mu \mathrm{g} / \mathrm{ml}$, $600 \mu \mathrm{g} / \mathrm{ml}$ and $750 \mu \mathrm{g} / \mathrm{ml})$ and cisplatin $(4.5 \mu \mathrm{g} / \mathrm{ml}$, $9.0 \mu \mathrm{g} / \mathrm{ml}, 13.5 \mu \mathrm{g} / \mathrm{ml}, 18.0 \mu \mathrm{g} / \mathrm{ml}$ ) followed by incubation for another $24 \mathrm{~h}$. The assay was carried out in triplicate. After $24 \mathrm{~h}$, treatment media was discarded and MTT $(5 \mathrm{mg} / \mathrm{ml})$ was added in each well and incubated for $4 \mathrm{~h}$. After incubation, MTT was discarded from the plate. Formazan crystals were solubilized by adding $100 \mu \mathrm{l}$ of DMSO in each well. A microplate reader (BioTek, USA) was used to record the absorbance at 570 $\mathrm{nm}$. The absorbance of untreated control well was taken as $100 \%$ and relative percent cell viability was calculated taking absorbance obtained from untreated control well as $100 \%$. \% cell viability was calculated by the formula:

Percent cell viability $=($ Absorbance of test $\times 100) / \mathrm{Ab}-$ sorbance of control [26]

$\mathrm{IC}_{50}$ values of cisplatin and MEUP were calculated by a four-parameter logistics model using Sigma Plot 12.0 (Systat Softwares Inc).

\section{Trypan blue exclusion assay}

The trypan blue exclusion assay is based on the principle that dead cells take the trypan blue dye due to their compromised cell membrane permeability [27]. The assay was carried out to determine the cytotoxicity caused by MEUP to A549 cancer cells. A549 cancer cells were seeded in 6 well plates ( 0.5 million/well) and kept for $24 \mathrm{~h}$ at $37^{\circ} \mathrm{C}$ and $5 \% \mathrm{CO}_{2}$ in a $\mathrm{CO}_{2}$ incubator. After $24 \mathrm{~h}$, media was discarded and cells were treated with different concentrations of MEUP $(300 \mu \mathrm{g} / \mathrm{ml}, 450 \mu \mathrm{g} /$ $\mathrm{ml}$, and $600 \mu \mathrm{g} / \mathrm{ml})$. Cisplatin was taken as the positive control ( $\mathrm{IC}_{50}$ concentration). After treatment, detached cells in media were taken in a tube while the live cells were harvested using trypsin and added in the same tube. A total of $100 \mu \mathrm{l}$ of cells were taken and mixed with $100 \mu \mathrm{l}$ of $0.4 \%$ trypan blue dye (1:1) and kept undisturbed for $4 \mathrm{~min}$. A drop of the mixture was taken in the Neubauer chamber and observed under the microscope and cell counting was done. Dead cells were identified by their ability to take blue color while the live cells did not take any color. Percent cell death was calculated by the formula [28]:

Percent cell death $=$ Dead cells $/$ Total cells X 100

\section{Evaluation of apoptosis (DAPI staining)}

4, 6 Diamino-2 phenylindole (DAPI) is a dye that binds to DNA strands robustly. The binding of DAPI with DNA strand gives fluorescence that can be detected under the fluorescence microscope [29]. For this, cells were seeded in a 12 wells plate $(1$ million cells/ well) and kept in a $\mathrm{CO}_{2}$ incubator under a humid condition for $24 \mathrm{~h}$ at $37^{\circ} \mathrm{C}$ and $5 \% \mathrm{CO}_{2}$. After incubation, media was discarded and cells were washed with PBS, followed by the treatment with cisplatin ( $\mathrm{IC}_{50}$ concentration) and different concentrations of MEUP $(300 \mu \mathrm{g} / \mathrm{ml}, 450 \mu \mathrm{g} /$ $\mathrm{ml}$, and $600 \mu \mathrm{g} / \mathrm{ml}$ ) for $24 \mathrm{~h}$. After treatment, $1 \mathrm{ml}$ of methanol was added in each well for 20 min for cell fixation. Cells were then washed with PBS followed by the addition of DAPI ( $300 \mathrm{nM})$ to each well and incubated for $30 \mathrm{~min}$. After incubation, dye was decanted from each well and cells were washed with PBS (1-2 ml) twice. Observations were made under a green fluorescence microscope after adding PBS [30, 31]. For quantitative estimation of effects of increasing concentration of MEUP on nuclear morphology, numbers of apoptotic cells/100 cells were measured [32, 33].

\section{Evaluation of antioxidant effect: determination of intracellular ROS}

DCFH-da assay was carried out to assess the ability of MEUP to reduce the intracellular reactive oxygen species. Cells were seeded in a 12-well plate $(1 \mathrm{million} /$ well $)$ and incubated for $24 \mathrm{~h}$ in a $\mathrm{CO}_{2}$ incubator at $37^{\circ} \mathrm{C}$ and $5 \% \mathrm{CO} 2$. After the incubation period, media was discarded from the wells and fresh media containing cisplatin $\left(\mathrm{IC}_{50}\right.$ concentration) and different concentrations of MEUP $(300 \mu \mathrm{g} / \mathrm{ml}, 450 \mu \mathrm{g} / \mathrm{ml}$, and $600 \mu \mathrm{g} / \mathrm{ml})$ were added and incubated for another $24 \mathrm{~h}$ at $37^{\circ} \mathrm{C}$ in a $\mathrm{CO}_{2}$ incubator under $5 \% \mathrm{CO}_{2}$ and humidified conditions. $\mathrm{H}_{2} \mathrm{O}_{2}(1 \mathrm{mM})$ was taken as the positive control. DCFHda was prepared in reduced serum in the final concentration of $1 \mu \mathrm{M}$. Cells were washed with phosphate 
buffer saline (PBS) and loaded with $200 \mu \mathrm{l}$ of dye and incubated for $30 \mathrm{~min}$ in dark. After the incubation period, cell washing was done with PBS twice and further loaded with PBS. Observations were made under the fluorescence microscope. Fluorescence intensity was quantified using the software ImageJ [34, 35].

\section{Preparation of drugs for in vivo administration}

Animal dosing was done according to their respective body weights. MEUP was dissolved in 10\% polyethylene glycol (PEG) 400. Cisplatin, cyclosporine, and cyclophosphamide were dissolved in normal saline. Ketoconazole was dissolved in water.

\section{Immunosuppression}

Immunosuppression of C57BL6 mice was done as per the protocol described by Jivrajani et.al [36]. Cyclosporine and ketoconazole were administered at a dose of 30 $\mathrm{mg} / \mathrm{kg}$ intraperitoneally and $10 \mathrm{mg} / \mathrm{kg}$ orally, respectively for 7 days. WBC count was taken on day 0 and day 7 to confirm the immunosuppression. Blood sampling was done in isoflurane-anesthetized animals from the retroorbital sinus and collected in 1.5- $\mathrm{ml}$ heparinized microcentrifuge tubes. WBC and lymphocyte counts were determined using an automated hematology analyzer (VetScan HM-5; Abaxis Inc., Union City, CA, USA). Cyclophosphamide was administered at a dose of $60 \mathrm{mg} /$ $\mathrm{kg}$ subcutaneously on days 1 and 3 before injecting tumor cells.

\section{Preparation of tumor cell line}

Semi-confluent A549 human lung cancer cells were detached by $0.25 \%$ trypsin. Cells were collected in a $15 \mathrm{ml}$ tube and centrifuged at $200 \times g$ for $5 \mathrm{~min}$ at $4{ }^{\circ} \mathrm{C}$. Supernatant media was decanted and the settled cells were washed with culture media by centrifugation at $200 \times g$ for $5 \mathrm{~min}$ at $4{ }^{\circ} \mathrm{C}$. The settled cells were finally suspended in a known volume of culture media. Cell counting was done using Neubauer's chamber. The viability of cells was determined by trypan blue exclusion assay. Collected cells were kept on ice and injected in animals immediately [36].

\section{Cancer cell implantation}

Immunocompromised C57BL6 mice (males, 4-6 weeks old) were selected for the study. The average weight of animals was between 25 and 30 grams. Prior to the injection of cancer cells, hairs from the shoulder blade of each animal were removed by waxing. Cells were injected in a volume of $0.1 \mathrm{ml} /$ mice containing about 5 million cells. Tumor volume was measured by a Vernier caliper on every alternate day. Treatment was started after the tumor volume reached between $80-100 \mathrm{~mm}^{3}$ [36].

\section{In vivo antitumor activity}

Tumor bearing mice having tumor volume between 80 and $100 \mathrm{~mm}^{3}$ were randomized and divided into 4 groups ( $n=6 /$ group) comprising of disease control (DC), positive control (PC), test group 1 (T1), and test group 2 (T2). Positive control (PC) received cisplatin (2 $\mathrm{mg} / \mathrm{kg}$ ) intraperitoneally (i.p.) twice a week as per the standard protocol [20,37-39]. The disease control group received $0.2 \mathrm{ml}$ of PBS orally. Test group 1 received a lower dose of MEUP $(200 \mathrm{mg} / \mathrm{kg})$ and test group 2 received a higher dose of MEUP $(400 \mathrm{mg} / \mathrm{kg}$ ) orally and once a day for 20 days. Tumor volume was measured every 4 days by the formula:

Volume $\left(\mathrm{mm}^{3}\right)=(A) \times\left(B^{2}\right) / 2$, where $A$ was the largest diameter $(\mathrm{mm})$ and $B$ the smallest $(\mathrm{mm})$. Treatment was continued for 20 days. Animals were sacrificed at the end of the study by $\mathrm{CO}_{2}$ asphyxiation; tumors were excised and weighed [36].

\section{Change in body weight and histopathological analysis}

Body weights of animals were taken on every alternate day to observe any severe fluctuations in their respective body weights. At the end of the study, vital organs (lung, kidney, spleen, liver, and heart) were excised and histopathology was done to check any signs of toxicity to vital organs. For histopathology, tissue specimens were fixed in $10 \%$ neutral buffered formalin and kept at $4{ }^{\circ} \mathrm{C}$ for 24 h. Specimens of kidneys, lungs, heart, liver, and spleen were cut into 3-4- $\mu \mathrm{m}$ thickness. Staining was done with hematoxylin and eosin. The sections were then analyzed under a microscope for any morphological changes [40].

\section{Statistical analysis}

Graph pad prism 8 and sigma plot 12.0 software were used to carry out the statistical analysis of the data. The $\mathrm{IC}_{50}$ value was analyzed by a four-parameter logistic model using the SigmaPlot 12.0 (Systat Software Inc.). One-way ANOVA and Student's $t$ tests were employed for multiple comparisons of groups. A $P$ value $<0.05$ was considered significant while the data was expressed as mean $\pm \mathrm{SD}$.

\section{Results}

Extraction and preliminary phytochemical screening The extraction of dried aerial parts of Uraria picta was carried out. The percent yield of methanolic extract was found to be $6.36 \% \mathrm{w} / \mathrm{w}$. Results from the preliminary phytochemical screening showed the presence of flavonoids, phenolics, glycosides, and tannins in the extract. The results were also in line with previous similar studies [41]. 
Estimation of total phenolic content

Estimation of total phenolics in MEUP was done by spectrophotometry. The standard curve of gallic acid was obtained and the concentration of total phenolics was calculated. Total phenolic content in MEUP was found to be 14.6 gallic acid equivalent (GAE) g/g. The results were conclusive that MEUP is rich in phenolic contents.

\section{Estimation of total flavonoid content}

Photometric estimation of total flavonoids was carried out by spectrophotometry. The standard curve of catechin was obtained. Total concentration of flavonoids was calculated and found to be 0.735 catechin equivalent (CE) $\mathrm{g} / \mathrm{g}$. The results were indicative of rich flavonoid content in MEUP.

\section{MTT assay}

Reduction in cell viability of A549 human lung cancer cells caused by different concentrations $(37.5-750 \mu \mathrm{g} /$ ml) of MEUP was tested after a 24-h interval. MEUP inhibited the proliferation of A549 cells in a dosedependent manner (Fig. 1a). The $\mathrm{IC}_{50}$ concentration of MEUP was observed to be $436.92 \mu \mathrm{g} / \mathrm{ml}$. For Cisplatin, $\mathrm{IC}_{50}$ concentration was observed to be $8.75 \mu \mathrm{g} / \mathrm{ml}$. A similar dose-dependent response on cell viability was also observed with cisplatin treatment (Fig. 1b). The pattern of cell proliferation was similar to that of results obtained in the trypan blue exclusion assay (discussed in the next section). Moreover, MEUP was found to be effective at higher concentrations. Results indicate that the extract has significant cytotoxic activity against A549 human lung cancer cells.

\section{Trypan blue exclusion assay}

MEUP, at all tested concentrations $(300 \mu \mathrm{g} / \mathrm{ml}, 450 \mu \mathrm{g} /$ $\mathrm{ml}$, and $600 \mu \mathrm{g} / \mathrm{ml}$ ) was found effective in controlling cell proliferation. A concentration-dependent increase in the inhibition of cell growth was observed (Fig. 2).

\section{Evaluation of apoptosis (DAPI staining)}

DAPI staining showed morphological characters that were suggestive of apoptotic cell death induced by MEUP. Condensed chromatin, nuclear fragmentation, and apoptotic bodies were visible in MEUP- and cisplatin-treated cells, when observed under a fluorescence microscope. Moreover, the proportion of apoptotic bodies was observed to increase in a dosedependent manner. The nuclear morphology of the control group remained intact (Fig. 3a). The increased number of apoptotic cells/100 cells was observed when the concentration of MEUP was increased (Figure 3b). The effect of the standard drug (cisplatin) and MEUP on cell death (apoptosis) was statistically significant. The $P$ value was less than $0.05(\mathrm{~F}(4,10)=35.86, P<0.001)$. Results were conclusive that both cisplatin and MEUP are capable of inducing apoptosis in cancer cells.

\section{Evaluation of antioxidant effect: determination of intracellular ROS}

Intracellular ROS levels were determined by DCFH-da staining assay. Microscopic images showed a decrease in intracellular ROS with an increase in the concentration of MEUP (Fig. 4a). Quantification of fluorescence intensity showed a dose-dependent decrease in intracellular ROS in MEUP-treated cells (Fig. 4b). While cisplatin (positive control) resulted in a multifold increase in intracellular ROS, a significant reduction in intracellular
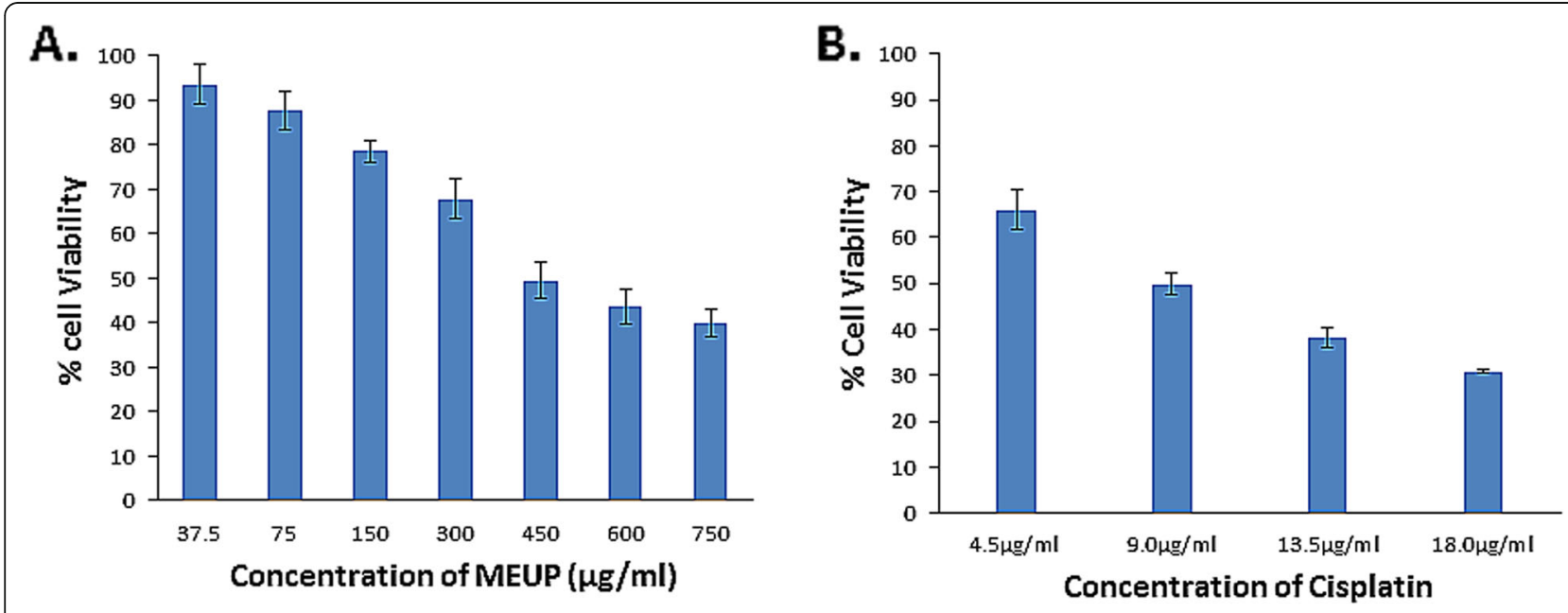

Fig. 1 Effects of MEUP (a) and cisplatin (b) on viability of A549 human lung cancer cells measured by MTT assay. Cells were cultured in varying concentrations of MEUP and Cisplatin. Reduction in cell viability was observed with increasing concentration of MEUP and Cisplatin. Results are expressed as mean \pm SD 


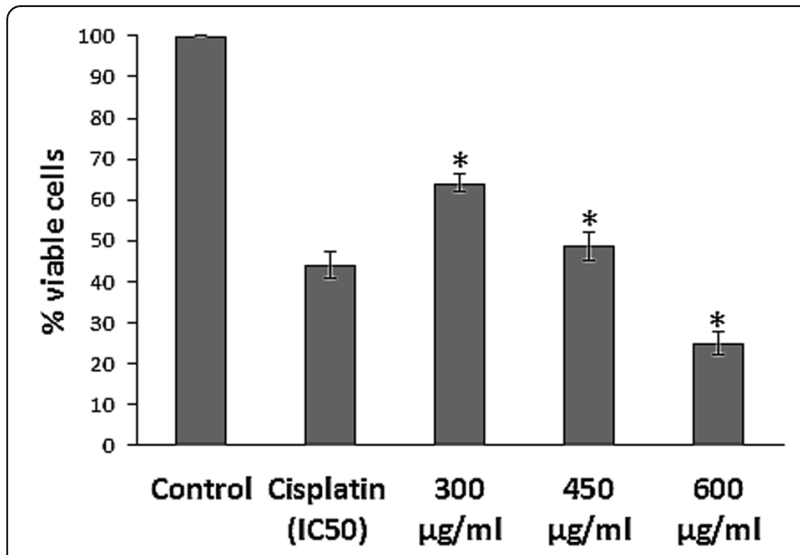

Fig. 2 Cytotoxic effect of MEUP and Cisplatin on A549 human lung cancer cells measured by trypan blue exclusion assay. Results are expressed as mean $\pm \mathrm{SD}$. The asterisk represents a significant difference in cell deaths between control and treatment groups. $(P<0.05)$
ROS was observed in cells treated with different concentrations of MEUP in comparison with control cells. The $P$ value was less than $0.05(\mathrm{~F}(4,10)=38.92, P<0.001)$. The results were conclusive that MEUP has a significant antioxidant property.

\section{Immunosuppression}

Treatment with cyclosporine and ketoconazole caused a significant immunosuppression in treated animals. The $P$ value was less than $0.05(t(46)=52.7, P<0.001)$ and $(t$ $(46)=47.29, P<0.001))$ for WBC and lymphocytes respectively. Figure 5 a shows a significant reduction in WBC and lymphocyte counts at the end of the treatment on day 7 when compared with the count on day 0

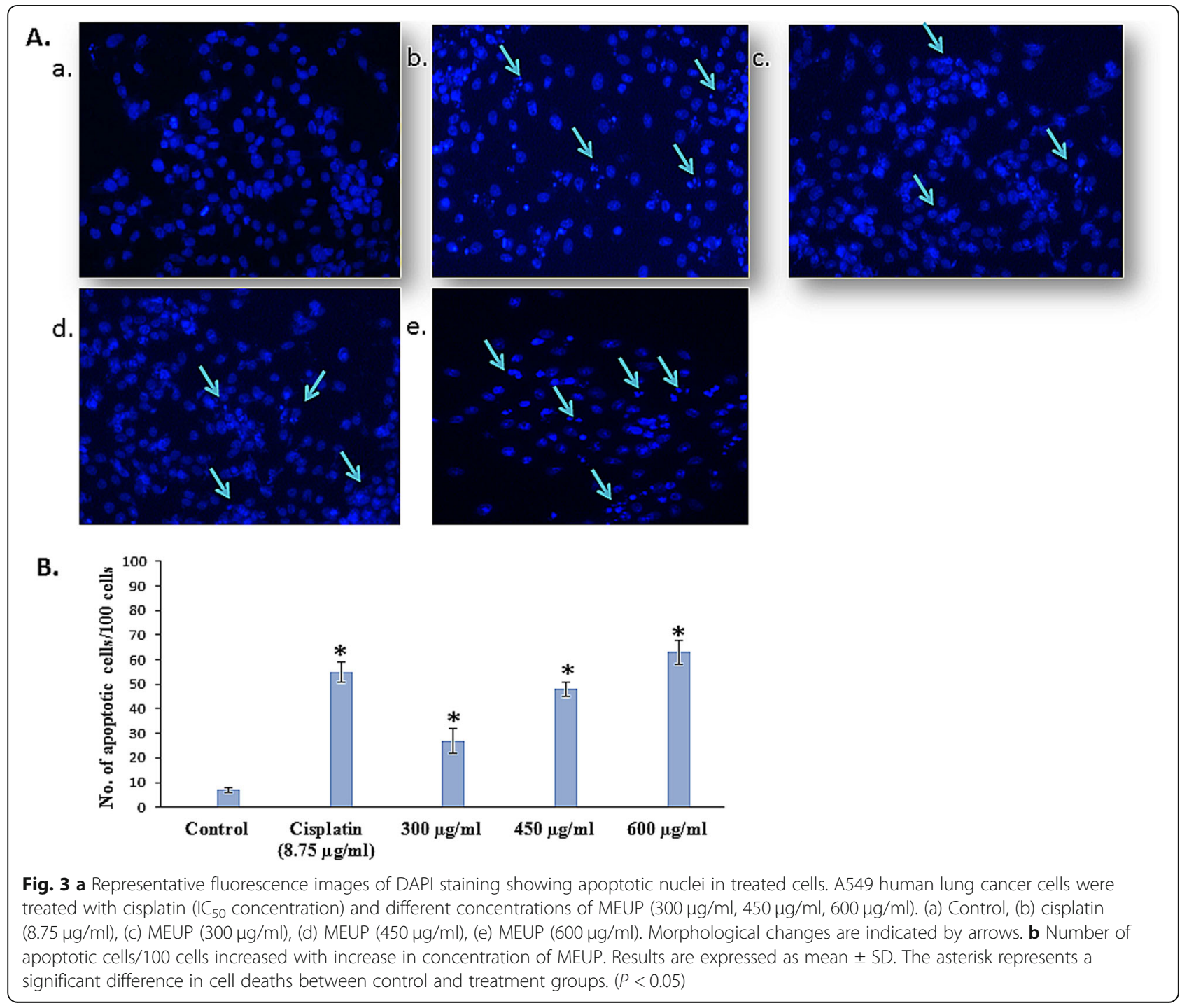


A.

a.

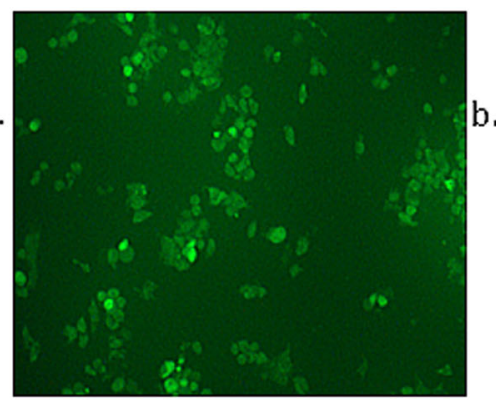

d.

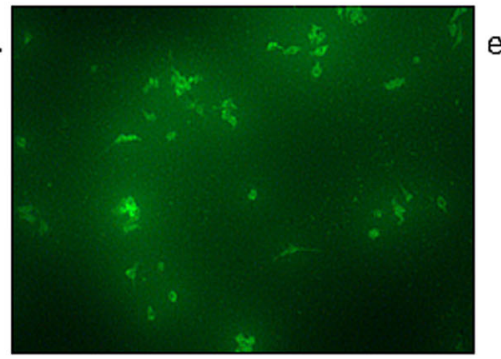

B.

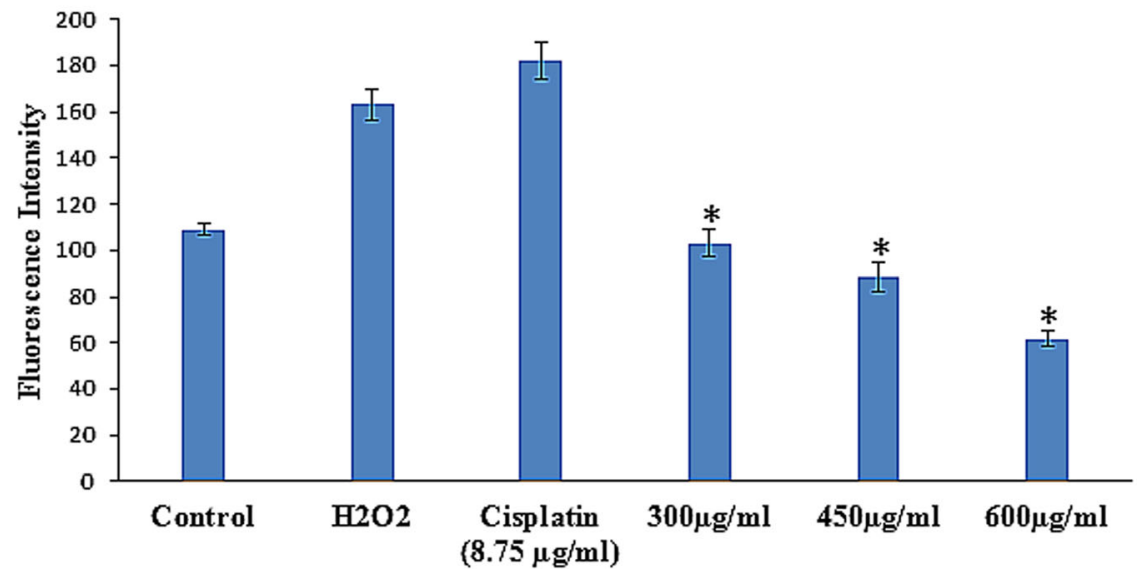
$(8.75 \mu \mathrm{g} / \mathrm{ml})$

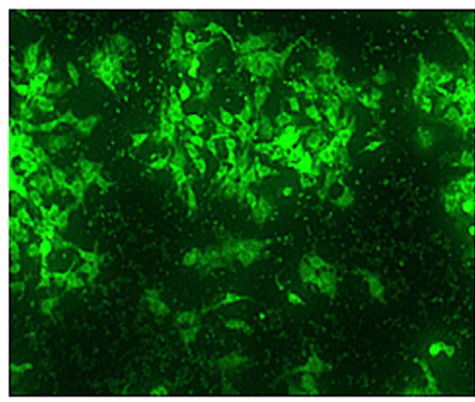

c.

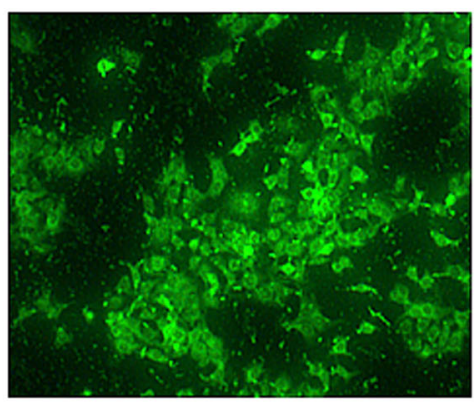

e.

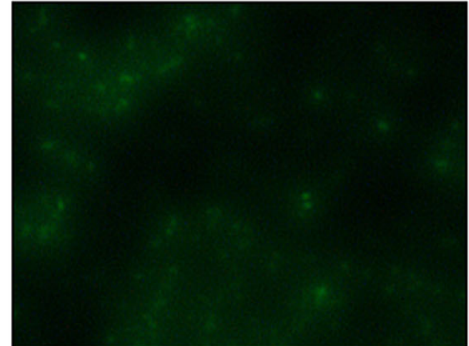

f.

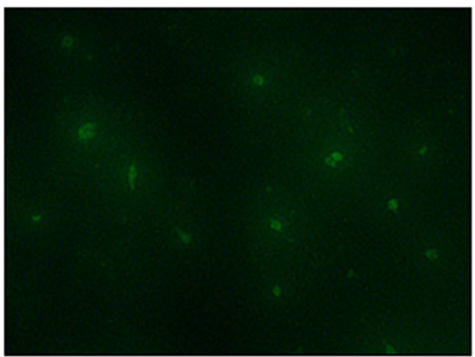

Fig. 4 Reactive oxygen species (ROS) determined by $\mathrm{H}_{2}$ DCF-da assay showing reduction in intracellular ROS in treatment groups. a Fluorescence microscopic images showing reduction in ROS in MEUP treated cells (a), negative control (b), positive control $\left(\mathrm{H}_{2} \mathrm{O}_{2}\right)(\mathrm{c})$, cisplatin (IC 50 concentration) (d), MEUP $(300 \mu \mathrm{g} / \mathrm{ml})(\mathrm{e}), \operatorname{MEUP}(450 \mu \mathrm{g} / \mathrm{ml})(\mathrm{f})$, MEUP $(600 \mu \mathrm{g} / \mathrm{ml})$. ROS levels were reduced in the cells with increasing concentration of MEUP. $\mathbf{b}$ Fluorescence intensity of $\mathrm{H}_{2} \mathrm{DCF}-\mathrm{da}$ in different treated cells determined by image $\mathrm{j}$ software. Results are expressed as mean \pm SD. The asterisk represents a significant difference in cell deaths between control and treatment groups. $(P<0.05)$

\section{In vivo antitumor studies}

The tumor volume of animals in each group was measured on every alternate day. A significant reduction in tumor volumes was observed in all groups treated with cisplatin and MEUP $(P<0.05)$. The diseased group showed consistent growth in tumor over the course of the study. Cisplatin (positive control) was most effective in reducing tumor growth. MEUP at a higher dose (400 $\mathrm{mg} / \mathrm{kg}$ ) caused a remarkable decrease in tumor volume. The lower dose of MEUP (200 mg/kg) was less effective in reducing tumor growth. However, tumor growth in test group I was less in comparison with the diseased group suggesting that the lower dose was also effective in controlling tumor growth (Fig. 5b, c). Similar results were also observed in weights of tumors excised at the end of the study from animals belonging to the test and control groups (Fig. 5d) $(P<0.05),(\mathrm{F}(3,20)=88.92, P<$ $0.001)$. The results are conclusive that both cisplatin (standard drug) and MEUP has significant antitumor properties.

\section{Change in body weight and histopathological analysis}

The body weight of animals was taken on every alternate day. No significant fluctuations in body weight of animals receiving MEUP were observed during the course of the study. However, a reduction in body weight was observed in the positive control (PC) receiving cisplatin and the diseased group (DC), apparently due to drug 


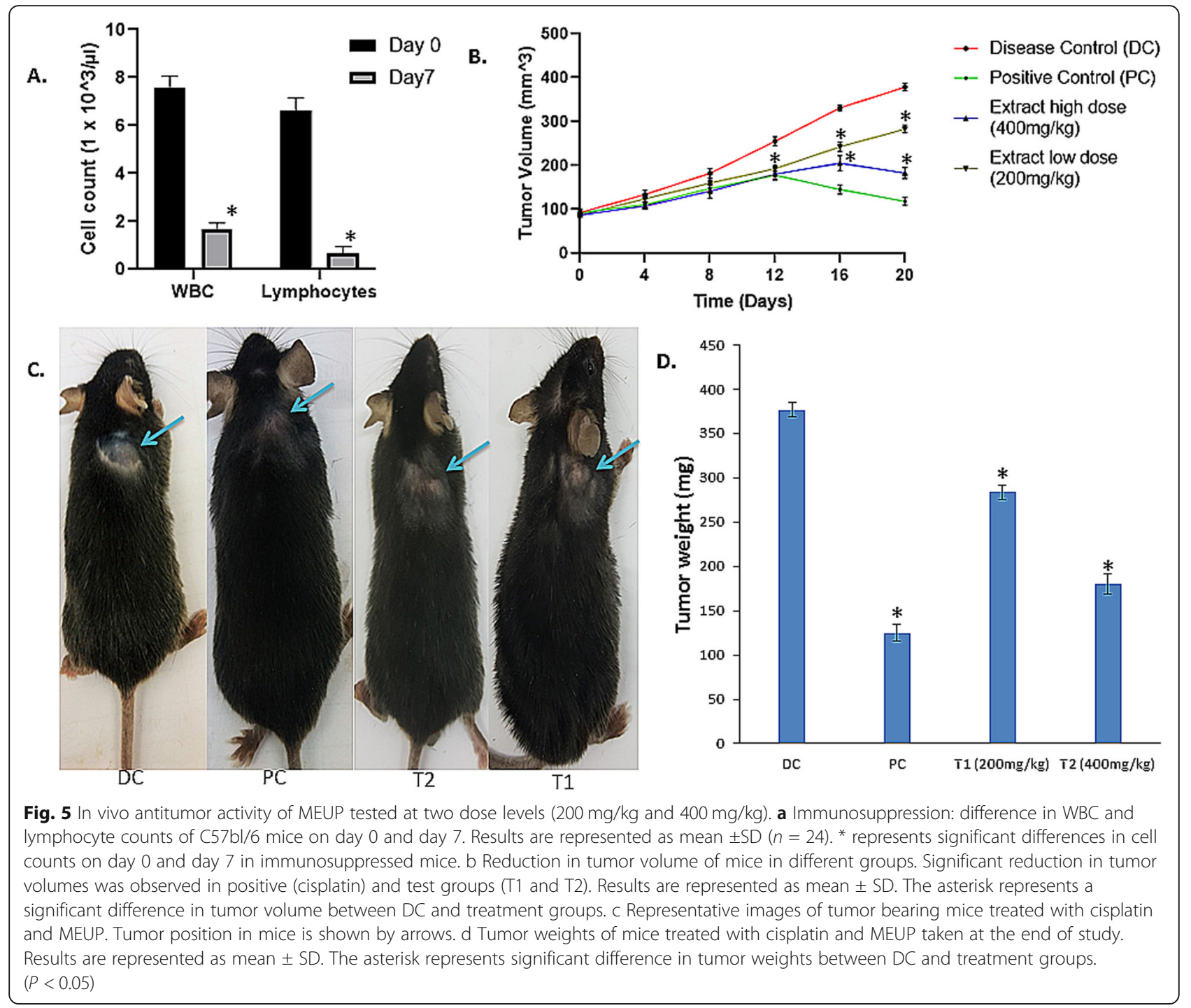

side effects and diseased condition, respectively (Fig. 6). Histopathological analysis of vital organs of animals from the control and the test groups receiving MEUP showed no signs of toxicity (Fig. 7).

\section{Discussion}

Plants and plant-derived phytoconstituents are utilized since time immemorial for the treatment of diseases. Ayurveda, the ancient and traditional system of medicine is mainly based on the use of different herbs to treat ailments [42, 43]. A major advantage of employing herbs as remedies is the occurrence of the least toxic effects on administration [8]. Moreover, their cost-effectiveness makes them further acceptable to the general population. A number of plants and plant-derived phytoconstituents have also established themselves as potential anticancer agents and are presently widely utilized as cytotoxic agents against cancer cells [44]. In that view,

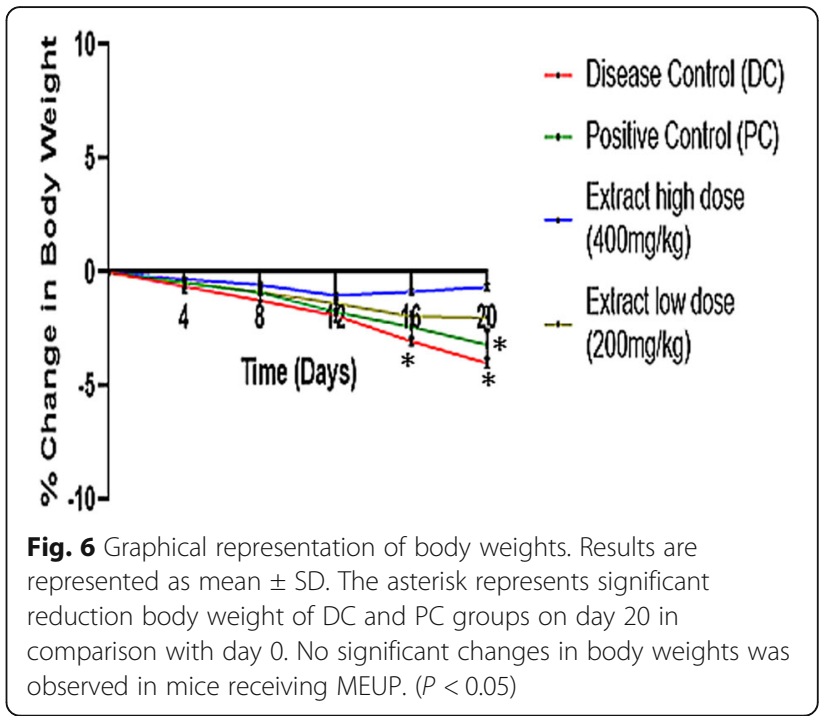




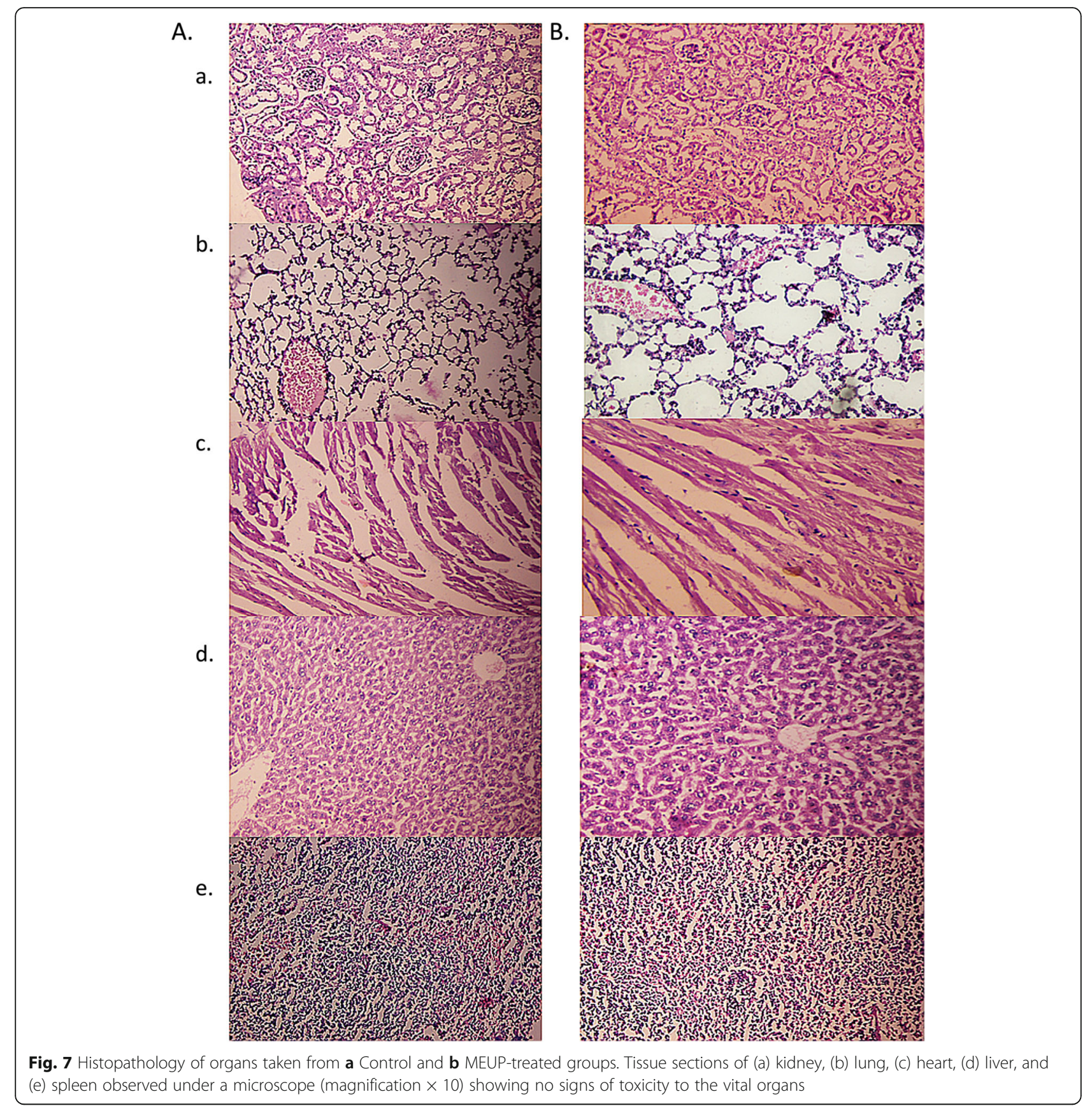

an attempt was made to evaluate the anticancer activity of Uraria picta (Jacq.) DC based on its traditional antiinflammatory and antioxidant uses. Our study showed that MEUP was able to reduce cancer growth in both, in vitro and in vivo models.

To begin with, we conducted the preliminary phytochemical screening of MEUP to determine the presence of different phytoconstituents in the extract. MEUP was found to be rich in different phytoconstituents including polyphenols, flavonoids, glycosides, and tannins. Several phenolic and flavonoid compounds have shown potential anticancer activities against different cancer cell lines. These include gallic acid, ferulic acid, cinnamic acid, caffeic acid, quercetin, luteolin, cisplatin, catechin, and epicatechin, to name a few [45-47]. Following that, we quantified the presence of total phenolics and flavonoids in the extract. The photometric estimation of MEUP for its phenolic and flavonoid contents suggested that the extract is rich in these classes of phytochemicals. Based on the data of phytochemical analysis, we proceeded to in vitro experiments to evaluate the 
anticancer potential of MEUP and possible mechanisms responsible for the anticancer effects of the extract.

Preliminary cytotoxic assays (MTT and trypan blue exclusion assay) showed a considerable reduction in the viability of A549 cancer cells when treated with different concentrations of MEUP (Figs. 1 and 2). A significant dose-dependent reduction in cell viability was observed in both assays. . Furthermore, MEUP was found to induce apoptosis in the treated cells. This was evident from the fluorescence images obtained after DAPI staining. A dose-dependent increase in morphological changes is evident from the results obtained (Fig. 3). Morphological features peculiar to apoptosis were seen in MEUP treated cells. Chromatin condensation, DNA fragmentation, and increased apoptotic bodies were observed.

Previously reported studies have shown that antioxidants prevent tumor growth through multiple mechanisms [39]. Based on the traditional claims and previously reported studies on antioxidant effects of the plant [18], we evaluated the ability of MEUP in reducing the oxidative stress or intracellular ROS in cancer cells. MEUP treatment showed a significant dose-dependent reduction in intracellular ROS in cancer cells. The observed reduction in cancer cell proliferation can therefore be partly attributed to the potential antioxidant effects of the extract.

Based on the promising results obtained in in vitro studies, we proceeded for the evaluation of antitumor effect of MEUP in tumor-bearing mice. Results from the in vivo experiments further supported the anticancer effects of MEUP. MEUP at both doses $(200 \mathrm{mg} / \mathrm{kg}$ and $400 \mathrm{mg} / \mathrm{kg}$ ) reduced tumor growth in tumor-bearing mice. However, similar to the results from in vitro experiments, MEUP was able to reduce tumor growth in a dose-dependent manner. MEUP at a higher dose (400 $\mathrm{mg} / \mathrm{kg}$ ) was found more effective. Moreover, MEUP was found to be safe, as no signs of toxicity were observed in animals receiving MEUP. Also, no significant fluctuations in body weights were observed in MEUP-treated groups.

Although an $\mathrm{IC}_{50}$ value of $436.92 \mu \mathrm{g} / \mathrm{ml}$ is too high to establish the crude methanolic extract of Uraria picta as a potential anticancer agent, the results from other in vitro and in vivo experiments conducted in our study clearly indicate that the plant has promising anticancer properties. Undoubtedly, further fractionation of the extract or identification and isolation of active anticancer molecules in Uraria picta will be beneficial in finding novel anticancer molecules. The anticancer effects of MEUP are largely attributable to the antioxidant, anti-inflammatory, and anticancer principles present in it. Reactive oxygen species (ROS) tend to act as the "two-edged swords" [48]. Cancer cells exist in a permanent condition of relatively higher oxidative stress. However, the increased oxidative stress by the intracellular ROS in cancer cells remains below the nonlethal levels. This increased oxidative stress in the cancer cells induces multiple signaling pathways that support proliferation [48, 49]. A further elevation in intracellular ROS may cross their nonlethal levels and induce apoptotic cell death [50]. On the contrary, a significant reduction in ROS inside the cancer cells reduces the oxidative stress-induced signaling pathways that support tumor growth [51, 52]. Plants based extracts consisting of antioxidants exert considerable cytotoxic effects on cancer cells [39]. Antioxidants are known for the differential regulation of transcriptional activator activities, and are also believed to prevent the formation of free radicals and DNA damage, thereby reducing the risk of cancer development $[39,53]$. Supportively, a significant effect of MEUP in reducing the intracellular ROS was observed in the DCFDA assay performed in our study. However, the mechanistic approaches adopted by MEUP against cancer growth cannot be only limited to its antioxidant effects, as merely a reduction in intracellular ROS cannot result in significant anticancer activity that is witnessed in our study. Moreover, the reduction in intracellular ROS can also be a result of anti-inflammatory effects of MEUP. Multiple studies have suggested ROS as a biomarker of chronic inflammation in cancer, owing to the fact that a considerably higher proportion of ROS is evident during chronic inflammation $[49,54]$. A potential link also exists between inflammation and cancer where inflammation tends to be highly supportive of cancer growth. Several anti-inflammatory agents have been shown to reduce tumor growth when tested in in vitro and in vivo models [15-17]. Supportively, the plant is known to have an excellent anti-inflammatory activity [18]. In addition, the anticancer/antitumor effect of MEUP is also partly attributable to its apoptosis inducing effects which is evident from our present study. It is also undoubtedly perceivable from the cytoxicity assays (MTT and trypan blue exclusion assays) and DAPI staining that apart from the antioxidant and anti-inflammatory principles, MEUP also comprises of anticancer principles that need further explorations. Also, the pathways that led to the induction of apoptosis by MEUP remain unexplored. The exact mechanism of action behind the anticancer activity of MEUP remains beyond the scope of this study. However, the antioxidant and antiinflammatory effects of the plant may have played crucial roles. Further studies on diverse sets of molecular pathways regulated by MEUP are needed to 
be explored to gain more insights into the anticancer potential of Uraria picta.

\section{Conclusion}

In conclusion, results from our study suggest that Uraria picta has significant anticancer properties. The plant extract can be further explored to unravel the mechanistic pathways that are employed by MEUP to exert its anticancer potential. Identification and isolation of active phytoconstituents from the plant may prove beneficial in finding novel agents for anticancer therapy.

\section{Abbreviations}

MEUP: Methanolic extract of Uraria picta; FDA: Food and Drug Administration; FBS: Fetal bovine serum; MTT: 3-(4, 5-Dimethylthiazol-2-yl)2,5-diphenyltetrazolium bromide; RPMI: Roswell Park Memorial Institute; DAPI: 4, 6 Diamino-2 phenylindole; DCFH-da: 2, 7-

Dichlorofluoresceindiacetate; NCCS: National Centre for Cell Science; IAEC: Institutional Animal Ethics Committee; GAE: Gallic acid equivalent: CE: Catechin equivalent; DMSO: Dimethyl sulfoxide; PBS: Phosphate buffer saline; ROS: Reactive oxygen species; H2O2: Hydrogen peroxide; WBC: White blood cells; DC: Disease control; PC: Positive control; SD: Standard deviation

\section{Acknowledgements}

The authors would like to thank B.V. Patel PERD Centre, Ahmedabad, for providing all the facilities to conduct the experiments.

\section{Plant authentication}

The plant was authenticated by a taxonomist, Department of Phytochemistry, B. V. Patel PERD Centre, Ahmedabad. A voucher specimen was submitted to the department. Voucher specimen number: BVPPERD/PP/ $1118 / 809$.

\section{Authors' contributions}

ASC and RB performed all the experiments. ASC prepared the manuscript. ASC and MN designed the study. All authors have read and approved the manuscript.

\section{Availability of data and materials}

The datasets used and/or analyzed during the current study available from the corresponding author on reasonable request.

\section{Ethics approval and consent to participate}

The protocol for the study was presented to the Institutional Animal Ethics Committee (IAEC). The protocol was approved on 20/10/2018 and an approval certificate was issued by the committee with Protocol number: PERD/IAEC/2018/014.

\section{Consent for publication}

Not applicable.

\section{Competing interests}

The authors declare that they have no competing interests.

\section{Author details}

${ }^{1}$ Department of Pharmacology and Toxicology, B. V. Patel Pharmaceutical Education and Research Development (PERD) Centre, Thaltej, Ahmedabad, Gujarat 380054, India. ${ }^{2}$ Institute of Pharmacy, Nirma University, SarkhejGandhinagar Highway, Ahmedabad 382481, Gujarat, India. ${ }^{3}$ Faculty of Science, NIRMA University, Sarkhej-Gandhinagar Highway, Ahmedabad, Gujarat 382481, India.
Received: 28 October 2019 Accepted: 26 December 2020

Published online: 11 January 2021

\section{References}

1. Olsen J, Overvad K (1993) The concept of multifactorial etiology of cancer. Pharmacol Toxicol 72(s1):33-38. https://doi.org/10.1111/j.1600-0773.1993. tb01666.x

2. Bray F, Ferlay J, Soerjomataram I, Siegel RL, Torre LA, Jemal A (2018) Global cancer statistics 2018: GLOBOCAN estimates of incidence and mortality worldwide for 36 cancers in 185 countries. CA Cancer J Clin 68(6):394-424. https://doi.org/10.3322/caac.21492

3. Jemal A, Siegel R, Ward E, Hao Y, Xu J, Murray T, Thun MJ (2008) Cancer Statistics 58(2):71-96. https://doi.org/10.3322/ca.2007.0010

4. Heron M (2017) Deaths: Leading Causes for 2015. Natl Vital Stat Rep 66(5):1-76

5. Alberg AJ, Brock MV, Ford JG, Samet JM, Spivack SD (2013) Epidemiology of lung cancer: diagnosis and management of lung cancer, 3rd ed: American College of Chest Physicians evidence-based clinical practice guidelines. Chest 143(5):e1S-e29S. https://doi.org/10.1378/chest.12-2345

6. Nurgali K, Jagoe RT, Abalo R (2018) Editorial: Adverse effects of cancer chemotherapy: anything new to improve tolerance and reduce sequelae? Front Pharmacol 9:245-245. https://doi.org/10.3389/fphar.2018.00245

7. Seca AML, Pinto DCGA (2018) Plant secondary metabolites as anticancer agents: successes in clinical trials and therapeutic application. Int J Mol Sci 19(1):263. https://doi.org/10.3390/ijms19010263

8. Greenwell M, Rahman PKSM (2015) Medicinal plants: their use in anticancer treatment. Int J Pharm Sci Res 6(10):4103-4112. https://doi.org/10.13040/ IJPSR.0975-8232.6(10).4103-12

9. Yadav AK, Yadav D, Shanker K, Verma RK, Saxena AK, Gupta MM (2009) Flavone glycoside based validated RP-LC method for quality evaluation of Prishniparni (Uraria picta). Chromatographia 69(7):653-658. https://doi.org/ 10.1365/s10337-009-0963-9

10. Saxena HO, Soni A, Mohammad N, Choubey SK (2014) Phytochemical screening and elemental analysis in different plant parts of Uraria picta Desv.: A Dashmul species. J Chem Pharm Res 6(5):756-760

11. Tandon N, Sharma M, Saraswathy A, Kn SK, Shakila R (2010) Quality standards of Indian Medicinal Plants. 8:340-345

12. Igboechi AC, Osazuwa EO, Igwe UE (1989) Laboratory evaluation of the acaricidal properties of extracts from Uraria picta (Leguminosae). Ethnopharmacol 26(3):293-298. https://doi.org/10.1016/03788741(89)90102-5

13. Mukhlesur Rahman M, Gibbons S, Gray Al (2007) Isoflavanones from Uraria picta and their antimicrobial activity. Phytochemistry 68(12):1692-1697. https://doi.org/10.1016/j.phytochem.2007.04.015

14. Singh NK (2017) Anti-inflammatory and hepatoprotective activities of the roots of Uraria picta. Int J Green Pharm 11(01):166-173

15. Coussens LM, Werb Z (2002) Inflammation and cancer. Nature 420(6917): 860-867. https://doi.org/10.1038/nature01322

16. Rakoff-Nahoum S (2006) Cancer issue: why cancer and inflammation? Yale J Biol Med 79(3-4):123

17. Rayburn ER, Ezell SJ, Zhang R (2009) Anti-inflammatory agents for cancer therapy. Mol Cell Pharmacol 1(1):29-43. https://doi.org/10.4255/ mcpharmacol.09.05

18. Tandon N, Sharma M, Saraswathy A, Kn SK, Ramachandran S (2010) Quality standards of Indian medicinal plants 8:340-345

19. Baksi R, Singh DP, Borse SP, Rana R, Sharma V, Nivsarkar M (2018) In vitro and in vivo anticancer efficacy potential of Quercetin loaded polymeric nanoparticles. Biomed Pharmacother 106:1513-1526. https://doi.org/10. 1016/j.biopha.2018.07.106

20. Wang Y, Chen L, Huang G, He D, He J, Xu W et al (2013) Klotho Sensitizes human lung cancer cell line to cisplatin via PI3k/Akt pathway. PLoS One 8(2):e57391. https://doi.org/10.1371/journal.pone.0057391

21. Singh J (2008) Maceration, percolation and infusion techniques for the extraction of medicinal and aromatic plants. Extraction technologies for medicinal and aromatic plants 67:32-35

22. Evans WC (2009) Trease and Evans pharmacognosy, international edition ebook, 194-353. Elsevier Health Sciences

23. Madaan R, Bansal G, Kumar S, Sharma A (2011) Estimation of total phenols and flavonoids in extracts of Actaea spicata roots and antioxidant activity studies. Indian J Pharm Sci 73(6):666-669. https://doi.org/10.4103/0250-474X. 100242 
24. Fattahi S, Zabihi E, Abedian Z, Pourbagher R, Ardekani AM, Mostafazadeh A, Akhavan-Niaki H (2014) Total phenolic and flavonoid contents of aqueous extract of stinging nettle and in vitro antiproliferative effect on hela and BT474 Cell lines. Int J Mol Cell Med 3(2):102

25. van Meerloo J, Kaspers GJ, Cloos J (2011) Cell sensitivity assays: the MTT assay. Methods Mol Biol 731:237-245. https://doi.org/10.1007/978-1-61779080-5_20

26. Shaikh MV, Kala M, Nivsarkar M (2017) Formulation and optimization of doxorubicin loaded polymeric nanoparticles using Box-Behnken design: exvivo stability and in-vitro activity. Eur J Pharm Sci 100:262-272. https://doi. org/10.1016/j.ejps.2017.01.026

27. Strober W (1997) Trypan blue exclusion test of cell viability. Curr Protoc Immunol 21(1):A.3B.1-A.3B.2. https://doi.org/10.1002/0471142735.ima03bs21

28. Crowley LC, Marfell BJ, Christensen ME, Waterhouse NJ $(2016,2016)$ Measuring cell death by trypan blue uptake and light microscopy. Cold Spring Harb Protoc (7):pdb-prot087155

29. Wallberg F, Tenev T, Meier P $(2016,2016)$ Analysis of apoptosis and necroptosis by fluorescence-activated cell sorting. Cold Spring Harb Protoc (4):pdb-prot087387

30. Patil MP, Jin X, Simeon NC, Palma J, Kim D, Ngabire D et al (2018) Anticancer activity of Sasa borealis leaf extract-mediated gold nanoparticles. Artif Cells Nanomed Biotechnol 46(1):82-88. https://doi.org/10.1080/ 21691401.2017.1293675

31. Ma G, Chong L, Li Z, Cheung AHT, Tattersall MHN (2009) Anticancer activities of sesquiterpene lactones from Cyathocline purpurea in vitro. Cancer Chemother Pharmacol 64(1):143-152. https://doi.org/10.1007/ s00280-008-0863-y

32. Pajaniradje S, Mohankumar K, Pamidimukkala R, Subramanian S, Rajagopalan R (2014) Antiproliferative and apoptotic effects of Sesbania grandiflora leaves in human cancer cells. Biomed Res Int 2014:474953-474953. https:// doi.org/10.1155/2014/474953

33. Balasubramanian K, Padma PR (2013) Anticancer activity of Zea mays leaf extracts on oxidative stress-induced Hep2 cells. J Acupunct Meridian Stud 6(3):149-158. https://doi.org/10.1016/j.jams.2013.01.015

34. Wu D, Yotnda P (2011) Production and detection of reactive oxygen species (ROS) in cancers. J Vis Exp 57:3357. https://doi.org/10.3791/3357

35. Khan I, Bahuguna A, Kumar P, Bajpai VK, Kang SC (2018) In vitro and in vivo antitumor potential of carvacrol nanoemulsion against human lung adenocarcinoma A549 cells via mitochondrial mediated apoptosis. Sci Rep 8(1):144. https://doi.org/10.1038/s41598-017-18644-9

36. Jivrajani M, Shaikh MV, Shrivastava N, Nivsarkar M (2014) An improved and versatile immunosuppression protocol for the development of tumor xenograft in mice. Anticancer Res 34(12):7177-7183

37. Huang Y, Zhou Y, Xia L, Tang J, Wen H, Zhang M (2018) Luteinizing hormone compromises the in vivo anti-tumor effect of cisplatin on human epithelial ovarian cancer cells. Oncol Lett 15(3):3141-3146. https://doi.org/ 10.3892/ol.2017.7655

38. Kawada M, Ohno Y, Ri Y, Ikoma T, Yuugetu H, Asai T et al (2001) Anti-tumor effect of gallic acid on LL-2 lung cancer cells transplanted in mice. Anticancer Drugs 12(10):847-852

39. Dhamija I, Kumar N, Manjula SN, Parihar V, Setty MM, Pai KSR (2013) Preliminary evaluation of in vitro cytotoxicity and in vivo antitumor activity of Premna herbacea Roxb. in Ehrlich ascites carcinoma model and Dalton's lymphoma ascites model. Exp Toxicol Pathol 65(3):235-242. https://doi.org/ 10.1016/j.etp.2011.08.009

40. Gautam MK, Goel RK (2014) Toxicological Study of $<$ i $>$ Ocimum sanctum</ i> Linn Leaves: Hematological, Biochemical, and Histopathological Studies. J Toxicol 2014:135654. https://doi.org/10.1155/2014/135654

41. Saxena HO, Mohan B, Kakkar A (2016) Assessment of variation in rhoifolin content in aerial parts of Uraria picta Desv. from different locations of Madhya Pradesh. J Pharm Res 10(5):185-190

42. Parasuraman S, Thing GS, Dhanaraj SA (2014) Polyherbal formulation: concept of ayurveda. Pharmacogn Rev 8(16):73-80. https://doi.org/10.4103/ 0973-7847.134229

43. Chhipa AS, Sisodia SS (2019) Indian medicinal plants with antidiabetic potential. J Drug Deli Therapeutics 9(1):257-265

44. Fridlender M, Kapulnik Y, Koltai H (2015) Plant derived substances with anticancer activity: from folklore to practice. Front Plant Sci 6:799-799. https:// doi.org/10.3389/fpls.2015.00799
45. Chahar MK, Sharma N, Dobhal MP, Joshi YC (2011) Flavonoids: a versatile source of anticancer drugs. Pharmacogn Rev 5(9):1-12. https://doi.org/10. 4103/0973-7847.79093

46. Niedzwiecki A, Roomi MW, Kalinovsky T, Rath M (2016) Anticancer efficacy of polyphenols and their combinations. Nutrients 8(9):552. https://doi.org/ 10.3390/nu8090552

47. Anantharaju PG, Gowda PC, Vimalambike MG, Madhunapantula SV (2016) An overview on the role of dietary phenolics for the treatment of cancers. Nutr J 15(1):99. https://doi.org/10.1186/s12937-016-0217-2

48. Wang J, Yi J (2008) Cancer cell killing via ROS: To increase or decrease, that is the question. Cancer Biol Ther 7(12):1875-1884. https://doi.org/10.4161/ cbt.7.12.7067

49. Liou G-Y, Storz P (2010) Reactive oxygen species in cancer. Free Radic Res 44(5):479-496. https://doi.org/10.3109/10715761003667554

50. Afanas'ev I (2011) Reactive oxygen species signaling in cancer: comparison with aging. Aging Dis 2(3):219-230

51. Zhang L, Li J, Zong L, Chen X, Chen K, Jiang Z et al (2016) Reactive oxygen species and targeted therapy for pancreatic cancer. Oxid Med Cell Longev 2016:1616781-1616781. https://doi.org/10.1155/2016/1616781

52. de Sá Junior PL, Câmara DAD, Porcacchia AS, Fonseca PMM, Jorge SD, Araldi RP, Ferreira AK (2017) The roles of ROS in cancer heterogeneity and therapy. Oxid Med Cell Longev 2017:2467940-2467940. https://doi.org/10. 1155/2017/2467940

53. Haq SH, Al-Ruwaished G, Al-Mutlaq MA, Naji SA, Al-Mogren M, Al-Rashed S et al (2019) Antioxidant, anticancer activity and phytochemical analysis of green algae, Chaetomorpha collected from the Arabian Gulf. Sci Rep 9(1): 18906. https://doi.org/10.1038/s41598-019-55309-1

54. Aggarwal V, Tuli HS, Varol A, Thakral F, Yerer MB, Sak K et al (2019) Role of reactive oxygen species in cancer progression: molecular mechanisms and recent advancements. Biomolecules 9(11). https://doi.org/10.3390/ biom 9110735

\section{Publisher's Note}

Springer Nature remains neutral with regard to jurisdictional claims in published maps and institutional affiliations.

\section{Submit your manuscript to a SpringerOpen ${ }^{\circ}$ journal and benefit from:}

- Convenient online submission

- Rigorous peer review

- Open access: articles freely available online

- High visibility within the field

- Retaining the copyright to your article

Submit your next manuscript at $>$ springeropen.com 